\title{
LETTER
}

\section{Patient-centered endpoints in trials of ICU sedation}

\author{
Jorge IF Salluh ${ }^{1,2^{*}}$ and Robert D Stevens ${ }^{3}$ \\ See related research by Zhou et al., http://ccforum.com/content/18/3/R122
}

We read with interest the study by Zhou and colleagues because it represents an important effort towards advancing the knowledge in current sedation strategies [1]. However, one crucial issue in sedation trials is to choose clinically relevant and patient-centered endpoints.

Recent randomized trials demonstrate that sedation strategies with similar short-term mortality rates and ICU length of stay may still be associated with different shortterm and long-term cognitive outcomes [2,3]. Limiting outcome evaluation to hospital mortality or length of stay may fail to capture important treatment effects. With converging evidence that survival of critically ill patients is rising, mortality is becoming an increasingly insensitive way to measure the efficacy of an intervention.

Multiple studies demonstrate that ICU delirium is a prevalent syndrome that can be detected with simple validated diagnostic tools $[4,5]$. ICU-acquired weakness is identified in nearly one-half of patients with sepsis, multiorgan failure, or protracted mechanical ventilation [6]. ICU-based trials need to focus on survivors and on the evaluation of other outcome domains such as delirium, long-term cognitive function, psychological status, muscle strength, functional status, and quality of life [3]. These endpoints are particularly relevant in designing trials of sedation strategies.

\section{Competing interests}

The authors declare that they have no competing interests.

\section{Author details}

${ }^{1} D^{\prime}$ Or Institute for Research and Education, Rua Diniz Cordeiro, 30 Botafogo, Rio de Janeiro 22281-100 RJ, Brazil. Praça Cruz Vermelha, 23, Centro 20230-130, Rio de Janeiro, RJ, Brazil. 'Division of Neurosciences Critical Care, The Johns Hopkins University School of Medicine, 733 North Broadway, Baltimore, MD 21205, USA.

Published online: 29 September 2014

\section{References}

1. Zhou Y, Jin X, Kang Y, Liang G, Liu T, Deng NI: Midazolam and propofol used alone or sequentially for long-term sedation in critically ill, mechanically ventilated patients: a prospective, randomized study. Crit Care 2014, 18:R122.

2. Pandharipande PP, Pun BT, Herr DL, Maze M, Girard TD, Miller RR, Shintani AK, Thompson JL, Jackson JC, Deppen SA, Stiles RA, Dittus RS, Bernard GR, Ely EW: Effect of sedation with dexmedetomidine vs lorazepam on acute brain dysfunction in mechanically ventilated patients: the MENDS randomized controlled trial. JAMA 2007, 298:2644-2653.

3. Pandharipande PP, Girard TD, Jackson JC, Morandi A, Thompson JL, Pun BT, Brummel NE, Hughes CG, Vasilevskis EE, Shintani AK, Moons KG, Geevarghese SK, Canonico A, Hopkins RO, Bernard GR, Dittus RS, Ely EW, BRAIN-ICU Study Investigators: Long-term cognitive impairment after critical illness. N Engl J Med 2013, 369:1306-1316.

4. Salluh JI, Soares M, Teles JM, Ceraso D, Raimondi N, Nava VS, Blasquez P, Ugarte S, Ibanez-Guzman C, Centeno JV, Laca M, Grecco G, Jimenez E, Árias-Rivera S, Duenas C, Rocha MG, Delirium Epidemiology in Critical Care Study Group: Delirium epidemiology in critical care (DECCA): an international study. Crit Care 2010, 14:R210.

5. Gusmao-Flores D, Figueira Salluh Jl, Chalhub RÁ, Quarantini LC: The confusion assessment method for the intensive care unit (CAM-ICU) and intensive care delirium screening checklist (ICDSC) for the diagnosis of delirium: a systematic review and meta-analysis of clinical studies. Crit Care 2012, 16:R115.

6. Stevens RD, Dowdy DW, Michaels RK, Mendez-Tellez PA, Pronovost PJ, Needham DM: Neuromuscular dysfunction acquired in critical illness: a systematic review. Intensive Care Med 2007, 33:1876-1891.

doi:10.1186/s13054-014-0536-7

Cite this article as: Salluh and Stevens: Patient-centered endpoints in trials of ICU sedation. Critical Care 2014 18:536.

* Correspondence: jorgesalluh@gmail.com

${ }^{1} D^{\prime}$ Or Institute for Research and Education, Rua Diniz Cordeiro, 30 Botafogo, Rio de Janeiro 22281-100 RJ, Brazil

${ }^{2}$ Praça Cruz Vermelha, 23, Centro 20230-130, Rio de Janeiro, RJ, Brazil

Full list of author information is available at the end of the article

\section{() Biomed Central}

C 2014 Salluh and Stevens; licensee BioMed Central Ltd. This is an Open Access article distributed under the terms of the Creative Commons Attribution License (http://creativecommons.org/licenses/by/4.0), which permits unrestricted use, distribution, and reproduction in any medium, provided the original work is properly credited. The Creative Commons Public Domain Dedication waiver (http://creativecommons.org/publicdomain/zero/1.0/) applies to the data made available in this article, unless otherwise stated. 